\title{
A Simple Fluorescent Chemosensor for Detection of Zinc Ions in Some Real Samples and Intracellular Imaging in Living Cells
}

\author{
Ayman A. A. Aziz, ${ }^{\circledR *, a}$ Amir E. Aboelhasan ${ }^{a}$ and Mostafa A. Sayed ${ }^{a}$ \\ ${ }^{a}$ Chemistry Department, Faculty of Science, Ain Shams University, Abbassia, 11566 Cairo, Egypt
}

\begin{abstract}
A new designed fluorescent chemosensor TYMN ((E)-1-((thiazol-2-ylimino)methyl) naphthalen-2-ol) for highly sensitive and selective tracing of trace amount of $\mathrm{Zn}^{2+}$ ions in some real samples was synthesized and characterized. The sensor TYMN can detect $\mathrm{Zn}^{2+}$ ions via fluorescence enhancement with a high selectivity over a wide range of metal ions, especially $\mathrm{Cd}^{2+}$. The sensor showed large fluorescence enhancement upon complexation with $\mathrm{Zn}^{2+}$ and simultaneous color change from yellow to orange. The limit of detection was analyzed to be $0.0311 \mu \mathrm{M}$ with a linear dynamic range $0.1-1.0 \mu \mathrm{M}$. The sensor could work in a $\mathrm{pH}$ span of 5.0-8.0. Based on the physicochemical and analytical methods like electrospray ionization (ESI)-mass, Job plot, ${ }^{1} \mathrm{H}$ nuclear magnetic resonance (NMR) and theoretical calculations, the detection mechanism for $\mathrm{Zn}^{2+}$ was explained based on restriction of internal charge transfer (ICT) mechanism. TYMN sensor was potentially utilized for $\mathrm{Zn}^{2+}$ ions concentration evaluation in some real samples. Fluorescence microscopy experiments revealed that probe TYMN may have application as a fluorophore to detect the $\mathrm{Zn}^{2+}$ in living cells.
\end{abstract}

Keywords: fluorescence, chemosensor, Schiff base, zinc recognition, DFT calculation, fluorescence bioimaging

\section{Introduction}

Recently, as a result of concern for human health and environmental safety, worldwide attention has been devoted to design and synthesize highly sensitive fluorescent probes for the selective recognition of heavy metal ions. ${ }^{1-7}$ Among the most important natural metal cations, zinc is the second most abundant metal ion that has a large biological spectrum of functions. ${ }^{8}$ Abnormal concentration of zinc causes frequent depressed immune function, accustom infections, bullous pustular dermatitis, diarrhea, alopecia, mental disturbances, metal fume fever, adult respiratory distress syndrome. ${ }^{9,10}$

For the important roles of $\mathrm{Zn}^{2+}$ ions in biochemistry, there were numerous techniques targeting $\mathrm{Zn}^{2+}$ sensing, such as atomic absorption spectroscopy (AAS), ${ }^{11,12}$ inductively coupled plasma atomic emission, ${ }^{13}$ anodic stripping voltammetry, ${ }^{14}$ potentiometry ${ }^{15}$ or spectrophotometry. ${ }^{16}$ However, the wide utilization of these methods is largely limited due to complicated sample preparation processes, time consuming, high cost, not easily adaptable for online monitoring, low sensitivity and some inherent interference especially with $\mathrm{Cd}^{2+}$ ions due to similar chemical properties.

*e-mail: aymanaziz31@gmail.com, aymanaziz31@sci.asu.edu.eg
To avoid such drawbacks, and using the special advantages of fluorescence criteria such as its easy performance, high sensitivity, genuine selectivity, fast, simple and real time response, ${ }^{17,18}$ various fluorescent probes have been developed for recognition of $\mathrm{Zn}^{2+}$ ions. ${ }^{19-25}$ Furthermore, for improving either the sensitivity and/or selectivity of $\mathrm{Zn}^{2+}$ sensing, Schiff bases as chemosensors have great attention. ${ }^{26-33}$

As an extension of our previous works $\mathrm{s}^{34-37}$ using Schiff bases as chemosensors, in the present work, we present a highly selective and sensitive novel fluorescence probe (E)-1-((thiazol-2-ylimino)methyl)naphthalen-2-ol (TYMN) which can detect $\mathrm{Zn}^{2+}$ via a fluorescence enhancement.

\section{Experimental}

\section{Materials and reagents}

All solvents were of reagent grade quality and were supplied from Merck (Darmstadt, Germany). Metal nitrate salts were used for preparation of metal ions solutions. $1 \mathrm{M}$ HEPES (4-(2-hydroxyethyl)-1-piperazineethanesulfonic acid) in $\mathrm{H}_{2} \mathrm{O}, 2$-aminothiazole and 2-hydroxy1-naphthaldehyde were supplied from Sigma-Aldrich (Saint Louis, MO, USA). TYMN sensor was dissolved in a mixed 
aqueous media dimethyl sulfoxide (DMSO): $\mathrm{H}_{2} \mathrm{O}$ (v/v, 1:9) to form $1 \mathrm{mM}$ stock solution. Metal salts were dissolved in $\mathrm{H}_{2} \mathrm{O}$ to get $10 \mathrm{mM}$ stock solutions. A stock solution of $\mathrm{Zn}^{2+}(1 \mathrm{mM})$ was prepared by dissolving $0.02974 \mathrm{~g}$ $\mathrm{Zn}\left(\mathrm{NO}_{3}\right)_{2} \cdot 6 \mathrm{H}_{2} \mathrm{O}$ in exactly $100 \mathrm{~mL}$ of deionized water and standardized with ethylenediamine tetraacetic acid (EDTA). ${ }^{38}$

\section{Characterization methods}

Jenway 6270 Fluorimeter was used for recording all fluorescence measurements. $\mathrm{pH}$ adjustment was carried out by using Jenway pH meter, model 3510, equipped with glass bodied combination pH electrode (924005). All the experiments were carried out at room temperature of $25 \pm 1{ }^{\circ} \mathrm{C}$. Elemental analyses (CHNS) were carried out using JEOL JMS-AX500 elemental analyzer. Fourier transform infrared (FTIR) spectrum of the chemosensor was obtained in $\mathrm{KBr}$ discs on a Unicam-Mattson 1000 FTIR. ${ }^{1} \mathrm{H}$ and ${ }^{13} \mathrm{C}$ nuclear magnetic resonance (NMR) spectra were performed on a Bruker Avance Drx $300-\mathrm{MHz}$ spectrometer with tetramethylsilane (TMS) as an internal standard. Time of flight mass spectrometry (TOF-MS) measurements were carried out on a JEOL JMS-AX 500 spectrometer. Flame atomic absorption spectrometry (FAAS) was used for the determination of zinc concentration at a wavelength of $213.9 \mathrm{~nm}, 30 \mathrm{~mA}$, band width $0.7 \mathrm{~nm}$ and air-acetylene gas. Microwave synthesis was performed in open glass vessel on a modified microwave oven model 2001 ETB with rotating tray and a power source $230 \mathrm{~V}$, microwave energy output $800 \mathrm{~W}$ and microwave frequency $2450 \mathrm{MHz}$. The surface morphology of the samples was evaluated by a scanning electron microscope (SEM, XL 30 ESEM, Philips) set at $20 \mathrm{kV}$. Prior to the examination, the samples were sputter coated with gold-palladium under argon atmosphere.

\section{Microwave assisted sensor synthesis of TMYN and} characterization data

As shown in Scheme 1, the novel sensor, (E)-3-((thiazol2-ylimino)methyl)naphthalen-2-ol (TYMN), was prepared according to the literature, ${ }^{39}$ with some modification under the effect of microwave radiation. A homogeneous mixture of 2-aminothiazole (2.0 g, $20 \mathrm{mmol})$, 2-hydroxy- 1-naphthaldehyde $(3.4 \mathrm{~g}, 20 \mathrm{mmol})$, acetic acid $(0.2 \mathrm{~mL})$ in methanol $(10 \mathrm{~mL})$, was put in a microwave reaction vessel equipped with a magnetic stirrer. The vessel was closed, and the reaction was irradiated at $50 \mathrm{~W}$ for $30 \mathrm{~s}$ interval for $3 \mathrm{~min}$. The solid was washed by aqueous sodium bisulfite solution and purified by recrystallization. FTIR and ${ }^{13} \mathrm{C}$ NMR spectra are depicted in Supplementary Information section as Figures S1 and S2.

Characteristics of TYMN were as follows: $\left(\mathrm{C}_{14} \mathrm{H}_{10} \mathrm{~N}_{2} \mathrm{OS}\right)$ molecular weight $/\left(\mathrm{g} \mathrm{mol}^{-1}\right)$ 254.31; yield: $86 \%$; mp 171-173 ${ }^{\circ} \mathrm{C}$; color: yellow; IR (KBr) $v / \mathrm{cm}^{-1} 3430,1610$, 1221, 712; ${ }^{1} \mathrm{H}$ NMR (400 MHz, DMSO) $\delta 13.82$ (s, $1 \mathrm{H}$, $\mathrm{OH}), 8.62(\mathrm{~s}, 1 \mathrm{H}, \mathrm{CH}=\mathrm{N}), 7.21-8.62(\mathrm{~m}, 6 \mathrm{H}$, aromatic, $2 \mathrm{H}$, thiazole); ${ }^{13} \mathrm{C}$ NMR (300 MHz, DMSO) $\delta 103.72,109.53$, $122.89,125.39,125.73,128.63,128.86,130.31,134.58$, 135.82, 139.60, 142.41, 149.73, 174.65; TOF-MS $\mathrm{m} / \mathrm{z}$, calcd. for $\mathrm{C}_{14} \mathrm{H}_{10} \mathrm{~N}_{2} \mathrm{OS}[\mathrm{M}+\mathrm{H}]^{+}: 255.47$, found: 255.25 . Elemental analysis calcd.: $\mathrm{C}, 66.12 ; \mathrm{H}, 3.96 ; \mathrm{N}, 11.02 ; \mathrm{S}$, $12.61 \%$; found: C, $67.00 ; \mathrm{H}, 3.59 ; \mathrm{N}, 11.10 ; \mathrm{S}, 12.31 \%$.

\section{Quantum yield measurement}

The fluorescence quantum yield $\phi_{\mathrm{S}}$ of TYMN chemosensor in EtOH was calculated employing the comparative William's method which involves the use of well-characterized standards with known quantum yield $\left(\phi_{\mathrm{R}}\right)$ values ${ }^{40}$ From the absorption and fluorescence spectra of probe, the quantum yield $\left(\phi_{S}\right)$ values were calculated according to equation $1: 41$

$\phi_{\mathrm{S}}=\phi_{\mathrm{R}} \frac{\mathrm{A}_{\mathrm{R}}}{\mathrm{A}_{\mathrm{S}}} \frac{\mathrm{I}_{\mathrm{R}}}{\mathrm{I}_{\mathrm{S}}} \frac{\eta_{\mathrm{R}}^{2}}{\eta_{\mathrm{S}}^{2}}$

where $\mathrm{S}$ and $\mathrm{R}$ stand for the sample and reference (quinine sulfate, $\phi_{\mathrm{R}}=0.54$ in $\left.0.05 \mathrm{M} \mathrm{H}_{2} \mathrm{SO}_{4}\right),{ }^{42}$ respectively; A represents the absorbance at the excitation wavelength; I refers to the integrated emission band areas at the excitation wavelength $(360 \mathrm{~nm})$, and $\eta$ is the solvent refractive index.

\section{General procedures for fluorogenic detection of $\mathrm{Zn}^{2+}$ using TYMN probe}

To $10 \mathrm{~mL}$ volumetric flasks containing different amounts of zinc ions, $1.0 \mathrm{~mL}$ of TYMN $(10 \mu \mathrm{M})$ was
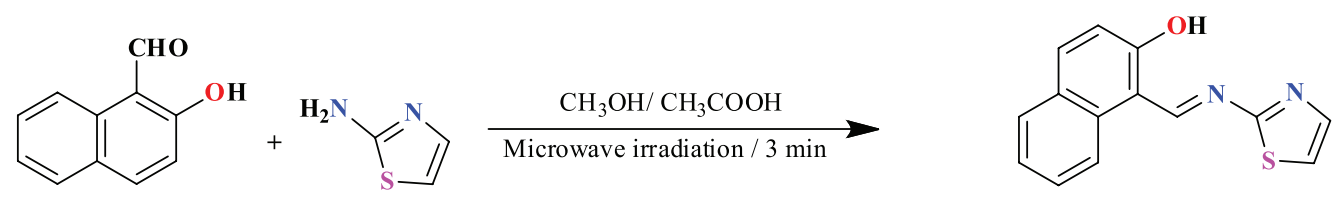

(E)-1-((thiazol-2-ylimino)methyl)naphthalen-2-ol

Scheme 1. Synthesis of probe TYMN ((E)-1-((thiazol-2-ylimino)methyl)naphthalen-2-ol). 
added directly, then the flask was completed to the mark by HEPES buffer solution ( $\mathrm{pH}$ 7.0). After shaking for $10 \mathrm{~s}$ and waiting for about $5 \mathrm{~min}$ at room temperature, $3 \mathrm{~mL}$ of the solution was put into the fluorescent cell and the fluorescence intensity was recorded immediately at an emission wavelength of $360 \mathrm{~nm}$. Each value was mean of three replicates.

\section{Sample preparation}

\section{Fruits and vegetable sample}

Fruits and vegetable samples (apple, grape, tomato and potato) were collected from the local market with plastic bags. The samples were rinsed in distilled water to remove dust and adhered particles, dried in an oven at ca. $60^{\circ} \mathrm{C}$, crushed with a porcelain mortar, and stored in doublecup polyethylene bottles. $2.0 \mathrm{~g}$ of the dried sample was transferred to a clean beaker and digested in $10 \mathrm{~mL}$ of a concentrated $\mathrm{HNO}_{3}(70 \%)$ by using a hotplate for ca. $30 \mathrm{~min}$. The mixture was filtered through a 0.45 -mm filter paper, after cooling at room temperature. The aliquot was quantitatively transferred to a $50 \mathrm{~mL}$ volumetric flask and completed with deionized water for analysis.

\section{Pharmaceutical samples}

\section{Vitazinc (capsules)}

A Vitazinc capsule was dissolved in about $5 \mathrm{~mL}$ aqua regia and the solution was evaporated to dryness. The process was repeated, then dissolved in $10 \mathrm{~mL}$ of deionized water and transferred quantitatively into $100 \mathrm{~mL}$ volumetric flask and completed with HEPES buffer ( $\mathrm{pH} 7.0$ ).

\section{Calamine lotion}

$1 \mathrm{~mL}$ portion of the lotion was dissolved in $10 \mathrm{~mL}$ of $2 \mathrm{M} \mathrm{HNO}_{3}$ and heated for several minutes to near boiling, then cooled, filtered and transferred quantitatively into $50 \mathrm{~mL}$ volumetric flask. The flask was then completed by HEPES buffer solution ( $\mathrm{pH}$ 7.0).

\section{3-(4,5-Dimethylthiazole-2-yl)-2,5-diphenyl tetrazolium bromide (MTT) assay}

The cell viability of the probe TYMN was tested against the living HeLa cell lines using the 3-(4,5-dimethylthiazole2-yl)-2,5-diphenyl tetrazolium bromide (MTT) assay. The cells were seeded into a well plate at a density of $1.5 \times 10^{4}$ cells per well and incubated in medium containing TYMN at concentrations ranging from 0 to $50 \mu \mathrm{M}$ for $30 \mathrm{~min}$. To each well, $100 \mu \mathrm{L}$ of MTT was added and the plates were incubated at $37{ }^{\circ} \mathrm{C}$ for $1 \mathrm{~h}$ to allow MTT to form formazan crystals by reacting with metabolically active cells. The medium with MTT was removed from the wells. Intracellular formazan crystals were dissolved by adding $100 \mu \mathrm{L}$ of DMSO to each well and the plates were shaken for $10 \mathrm{~min}$. The absorbance was recorded using plate reader (Multiskan EX; Thermo Fisher Scientific Inc., Waltham, MA, USA).

\section{Cell culture and fluorescence bio-imaging}

TYMN sensor was used for in vitro fluorescence imaging of zinc in HeLa cells. Dulbecco's modified Eagle's medium (DMEM) containing 10\% fetal bovine serum (FBS) was used to maintain the living HeLa cells at $37{ }^{\circ} \mathrm{C}$ in a humidified incubator provided with $5 \% \mathrm{CO}_{2}$. Afterward, the cells were washed with HEPES buffer for several times to remove the residual DMEM medium and dead cells. In HEPES buffer, $\mathrm{pH}=7.0$, holding $1 \%$ DMSO as co-solvent for $30 \mathrm{~min}$ at $37^{\circ} \mathrm{C}$, HeLa cells were incubated with TYMN $(10.0 \mu \mathrm{M})$. To eradicate excess of TYMN in the extracellular medium, the incubated cells were swabbed with HEPES for several times. To eradicate excess of TYMN in the extracellular medium, the incubated cells were swabbed with HEPES for several times, then subjected to fluorescence imaging. The HeLa cells were then further allowed to incubate with with $\mathrm{Zn}^{2+}(20 \mu \mathrm{M}$ in HEPES buffer) for $10 \mathrm{~min}$ at $37{ }^{\circ} \mathrm{C}$ and were then subjected to fluorescence imaging using a CarlZeiss LSM 710 confocal microscope system (Germany)

\section{Results and Discussion}

The Schiff base (TYMN) was designed and green synthesized by condensation between 2-hydroxy1-naphthaldehyde and 2-aminothiazole under microwave conditions in high yields. Its structure was confirmed by FTIR, ${ }^{1} \mathrm{H}$ NMR, ${ }^{13} \mathrm{C}$ NMR, TOF-MS and X-ray analysis. The full crystallographic data can be found in our previous work. ${ }^{39}$

\section{Morphology of TYMN and its $\mathrm{Zn}$ " complex}

The morphological properties of TYMN and its $\mathrm{Zn}^{2+}$ complex were characterized by SEM. The SEM micrographs are depicted in Figure 1. The SEM analysis provides a strong evidence for $\mathrm{Zn}^{2+}$ coordination to TYMN via significant changes in the surface morphology. The SEM micrograph of TYMN sensor demonstrates nonuniform platelet-like structure associated with variable lateral dimensions. On contrast, the SEM micrographs of TYMN-Zn complex exhibits a tube-like morphology. 
Moreover, uniform matrix of the synthesized $\mathrm{Zn}$ complex was clearly noticed in the pictograph.

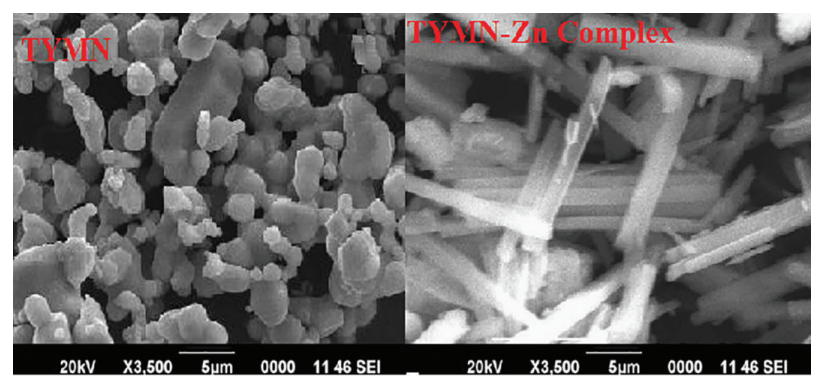

Figure 1. Scanning electron microscopy images of TYMN and TYMNZn complex.

\section{Photophysical properties of TYMN sensor}

The affinity of the TYMN sensor towards numerous metal ions was performed by recording UV-Vis absorption and emission spectra in mixed solvent $\mathrm{DMSO} / \mathrm{H}_{2} \mathrm{O}$ system ( v/v, 1:9, 5 mM, HEPES buffer, $\mathrm{pH} 7.0$ ), where DMSO was used as a co-solvent. As shown in Figure 2, the absorption spectrum of TYMN $(5.0 \mu \mathrm{M})$ exhibited two bands, at $316 \mathrm{~nm}$ which can be attributed to $\pi-\pi^{*}$ transition of the conjugated system including benzene ring and the double bond of the azomethine group and at $356 \mathrm{~nm}$ due to $\mathrm{n}-\pi^{*}$ transition of non-bonding electrons present on the nitrogen of the azomethine group. Upon addition of $5.0 \mu \mathrm{M} \mathrm{Zn}^{2+}$ (1 equivalent), a new absorption signal appeared at $469 \mathrm{~nm}$ with color change of TYMN color from yellow to orange (Figure 2 inset). The formation of new absorption band was ascribed to the formation of TYMN-Zn complex with different color from that of the sensor. On the contrary, addition of other competitive metal ions, such as $\mathrm{Co}^{2+}, \mathrm{Ni}^{2+}$,

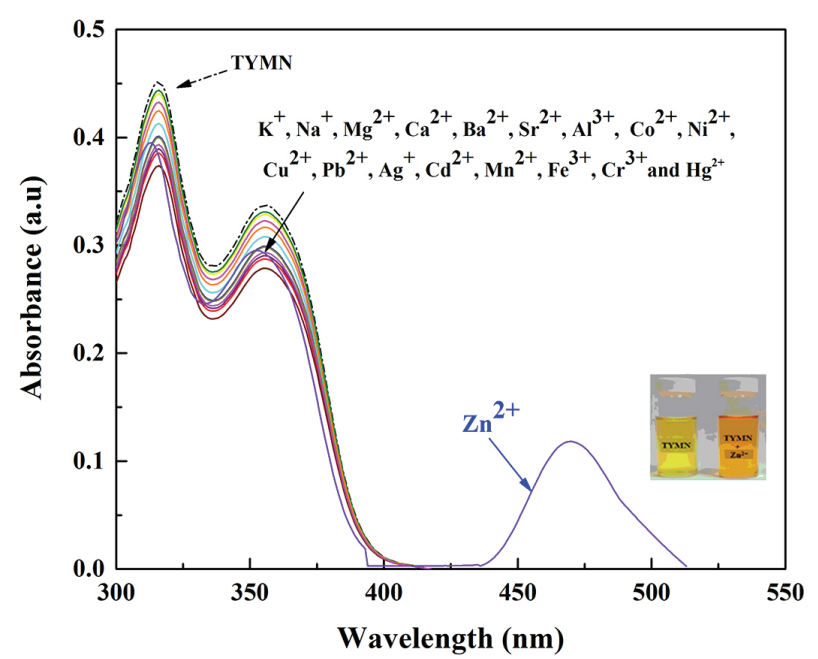

Figure 2. Absorption spectra of TYMN $(10 \mu \mathrm{M})$ in $10 \%(\mathrm{v} / \mathrm{v})$ DMSO/ $\mathrm{H}_{2} \mathrm{O}$ buffered by $5 \mathrm{mM}$ HEPES at $\mathrm{pH} 7.0$ at $25^{\circ} \mathrm{C}$, upon addition of various 5 equiv. metal ions.
$\mathrm{Cu}^{2+}, \mathrm{Pb}^{2+}, \mathrm{Ag}^{+}, \mathrm{Cd}^{2+}, \mathrm{Mn}^{2+}, \mathrm{Fe}^{3+}, \mathrm{Cr}^{3+}, \mathrm{Hg}^{2+}, \mathrm{K}^{+}, \mathrm{Na}^{+}, \mathrm{Mg}^{2+}$, $\mathrm{Ca}^{2+}, \mathrm{Ba}^{2+}, \mathrm{Sr}^{2+}$, and $\mathrm{Al}^{3+}$, no intrinsic absorbance changes were observed. The results demonstrated that TYMN is characteristic of high selectivity toward $\mathrm{Zn}^{2+}$ over other competitive metal ions.

TYMN sensor fluorescence properties were evaluated with distinguished metal ions in $\mathrm{DMSO} / \mathrm{H}_{2} \mathrm{O}$ system $(\mathrm{v} / \mathrm{v}$, 1:9, $50 \mathrm{mM}$ HEPES, $\mathrm{pH} 7.0$ ) at $25^{\circ} \mathrm{C}$. The sole sensor TYMN $(10 \mu \mathrm{M})$ exhibited a weak characteristic fluorescence emission at $586 \mathrm{~nm}$ (quantum yield, $\Phi=0.026$ ), upon excitation at wavelength $360 \mathrm{~nm}$ (Figure 3). The weak fluorescence intensity may be attributed to internal charge transfer which quench the sensor fluorescence emission. As shown in Figure 3, upon addition of various metal ions, the emission spectra of TYMN nearly did not alter, except on exposure to $\mathrm{Zn}^{2+}(10 \mu \mathrm{M})$, the emission profile shows a specific enhancement in the fluorescence intensity, demonstrating that TYMN behaves as an efficient and selective sensor for $\mathrm{Zn}^{2+}$ over other competitive essential metal ions tested.

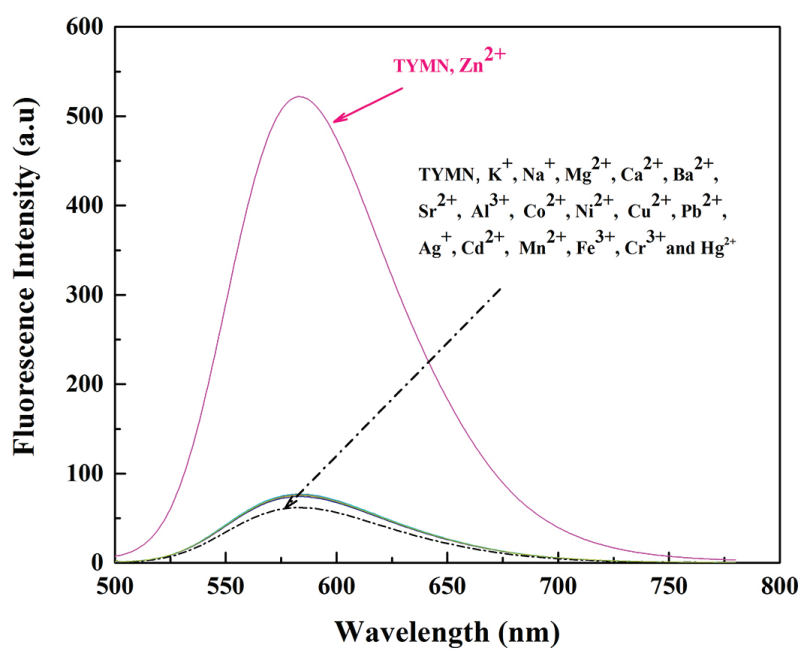

Figure 3. Fluorescence spectra of TYMN sensor $\left(5.0 \mu \mathrm{M}, \lambda_{\mathrm{ex}}=360 \mathrm{~nm}\right.$, $\left.\lambda_{\mathrm{em}}=583 \mathrm{~nm}\right)$ in presence of some essential metal ions $\left(\mathrm{DMSO} / \mathrm{H}_{2} \mathrm{O}, \mathrm{v} / \mathrm{v}\right.$, 1:9; 5 mM, HEPES buffer: $\mathrm{pH} 7.0$ ).

Effect of $\mathrm{pH}$ on $\mathrm{Zn}^{2+}$ binding with TYMN

The applicability of the TYMN sensor under physiological conditions was checked by investigation of the influence of $\mathrm{pH}$ on fluorescence response of TYMN sensor to $\mathrm{Zn}^{2+}$ ions at different $\mathrm{pH}$ at $\lambda_{\text {em }}=583 \mathrm{~nm} .{ }^{43}$ The effect of $\mathrm{pH}$ on the fluorescence response of TYMN probe and its $\mathrm{Zn}^{2+}$ complex was investigated in DMSO/ $\mathrm{H}_{2} \mathrm{O}(1: 9, \mathrm{v} / \mathrm{v})$ mixture (Figure 4$)$. The $\mathrm{pH}$ of solution was regulated by buffers of $\mathrm{KCl} / \mathrm{HCl}(\mathrm{pH} 1.0-2.0)$, $\mathrm{CH}_{3} \mathrm{COOH} / \mathrm{NaOH}$ (pH 3.0-4.0), MES (2-( $N$-morpholino) ethanesulfonic acid)/NaOH ( $\mathrm{pH}$ 4.5-6.0), HEPES 
(pH 6.5-9.0) and Tris/NaOH (pH 10.0-12.0). The results showed that the fluorescence profile of TYMN individually does not undergo any noticeable change, whereas in presence of $\mathrm{Zn}^{2+}$ ion, the fluorescence intensity was enhanced. At $\mathrm{pH}>3.0$, the fluorescence emission intensity of TYMN-Zn significantly increases and remain constant in the range 5.0-8.0 and then begin to decrease again, because of phenolic-OH deprotonation and availability of lone pair on azomethine nitrogen atom. The decrease in fluorescence response of TYMN probe at $\mathrm{pH}<5.0$ arises from proton binding by imine nitrogen. ${ }^{44} \mathrm{On}$ the other hand, the receded decreases in fluorescence response at $\mathrm{pH}>8.0$ could be attributed to the formation of $\mathrm{Zn}^{2+}$ ion hydroxides. ${ }^{45}$ Hence, HEPES buffer solution ( $\mathrm{pH} 7.0$ ) was chosen as the working moiety for further studies.

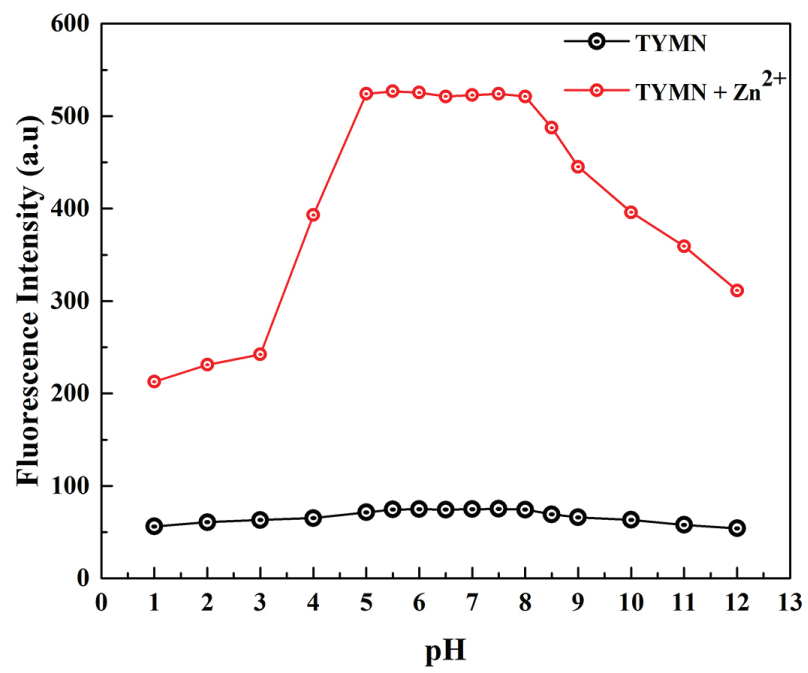

Figure 4. Fluorescence intensities $\left(\lambda_{\mathrm{ex}}=360 \mathrm{~nm}, \lambda_{\mathrm{em}}=583 \mathrm{~nm}\right)$ of TYMN $(10.0 \mu \mathrm{M})$ in the absence (black plots) and presence (red plots) of $\mathrm{Zn}^{2+}$ (5 equiv.) at various $\mathrm{pH}$ values.

\section{Response time}

For real time applications, as a crucial factor, TYMN fluorescence response in absence and in presence of $\mathrm{Zn}^{2+}$ ions were correlated with a time course at an emission wavelength of $583 \mathrm{~nm}$ at ordinary room temperature. As shown in Figure 5 with the increase of the reaction time, the fluorescence intensity of TYMN sensor with $\mathrm{Zn}^{2+}$ increased and reached equilibrium within $5 \mathrm{~min}$ and then almost no change in the fluorescence intensity within $1 \mathrm{~h}$ was observed. These indicated that sensor TYMN could serve as an efficient probe for $\mathrm{Zn}^{2+}$ quickly and reliably.

Sensitivity and limit of detection (LOD)

To address the sensitivity, TYMN fluorescence responses along with increasing $\mathrm{Zn}^{2+}$ ion concentration were investigated (Figure 6). The results indicated that, upon subsequent gradual increase in $\mathrm{Zn}^{2+}$ ion concentration in the range 1.0 to $10 \mu \mathrm{M}$, fluorescence intensity increases in a dramatic manner. A linear plot was constructed with average values of the intensities against the concentration of $\mathrm{Zn}^{2+}$ ions for determining the slope (Figure 7). The limit of detection was estimated to be 0.0311 on the base of the equation $\left(\mathrm{LOD}=3 \mathrm{~S}_{\mathrm{b}} / \mathrm{S}, \mathrm{n}=10\right)$, and a precision of $3.2 \%$ relative standard deviation (RSD) were achieved, ${ }^{46}$ where $S_{b}$ is the standard deviation of the blank solution and $\mathrm{S}$ is the slope between fluorescence intensity versus sample concentration.

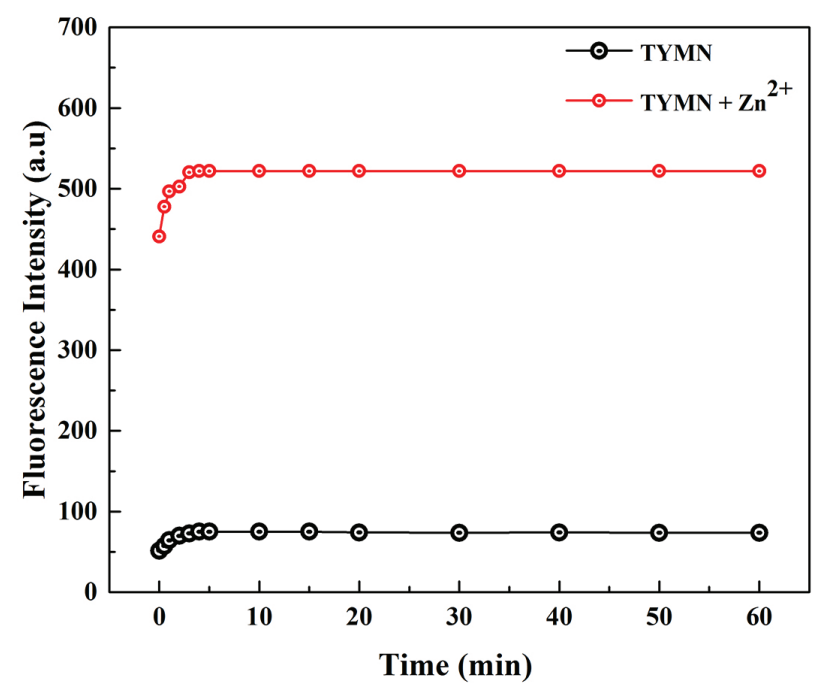

Figure 5. Effect of time on the fluorescence intensity of TYMN $(10.0 \mu \mathrm{M})$ in absence of $\mathrm{Zn}^{2+}$ and in presence of $\mathrm{Zn}^{2+}$ ion (5 equiv.) $\left(\lambda_{\mathrm{ex}}=360 \mathrm{~nm}\right.$, $\lambda_{\mathrm{em}}=583 \mathrm{~nm}$ ).

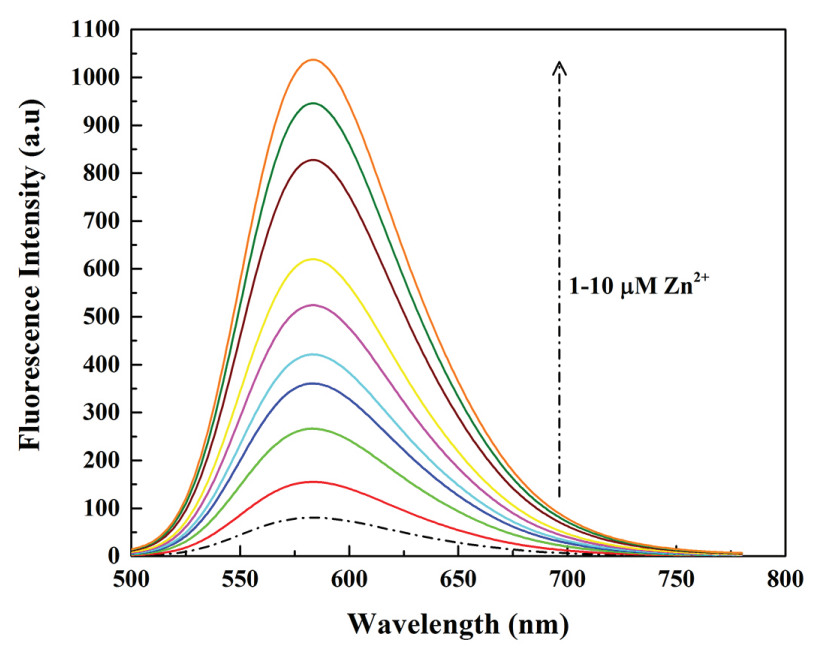

Figure 6. Fluorescence response of sensor TYMN $(10 \mu \mathrm{M})$ titrated with 0.0-1.0 equiv. of $\mathrm{Zn}^{2+}$ solutions in DMSO/ $\mathrm{H}_{2} \mathrm{O}(\mathrm{v} / \mathrm{v}, 1: 9,0.05 \mathrm{mM}$ HEPES, $\mathrm{pH} 7.0$ ) solutions ( $\left.\lambda_{\mathrm{ex}}=360 \mathrm{~nm}, \lambda_{\mathrm{em}}=583 \mathrm{~nm}\right)$.

\section{TYMN sensor selectivity}

To demonstrate the practical applicability of the TYMN-Zn fluorescence sensing system, potential 


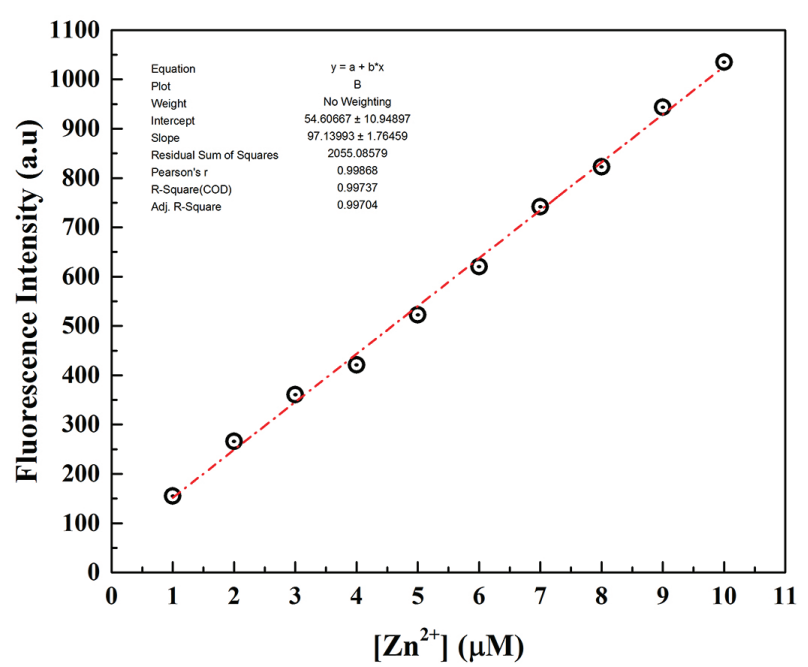

Figure 7. Calibration curve of TYMN-Zn complex $\left(\lambda_{\mathrm{ex}}=360 \mathrm{~nm}\right.$, $\left.\lambda_{\mathrm{em}}=583 \mathrm{~nm}\right)$.

interferences from the more importantly coexisting species frequently encountered in environmental and biological sample matrices were investigated. The selectivity of TYMN $(5 \mu \mathrm{M})$ towards the competing ions $(50 \mu \mathrm{M})$ were investigated in $\mathrm{DMSO} / \mathrm{H}_{2} \mathrm{O}$ (v/v, 1:9, $0.05 \mathrm{mM}$ HEPES, $\mathrm{pH}$ 7.0) solutions in the absence (as a blank control) and presence of $\mathrm{Zn}^{2+}(10 \mu \mathrm{M})$. The selectivity of TYMN probe towards the studied metal ions was identified by calculating relative error $\mathrm{RE}(\%)=\left[\left(\mathrm{F}-\mathrm{F}_{0}\right) / \mathrm{F}_{0}\right] \times 100$, where $\mathrm{F}_{0}$ and $\mathrm{F}$ are the fluorescence intensity in absence and in presence of some interfering ion. Figure 8 demonstrated that the observed relative error was considered as tolerable, reflecting the low interference and high selectivity of the proposed probe.

\section{TYMN sensor reversibility and cyclicity indexes}

For practical applications, reversibility and circularity

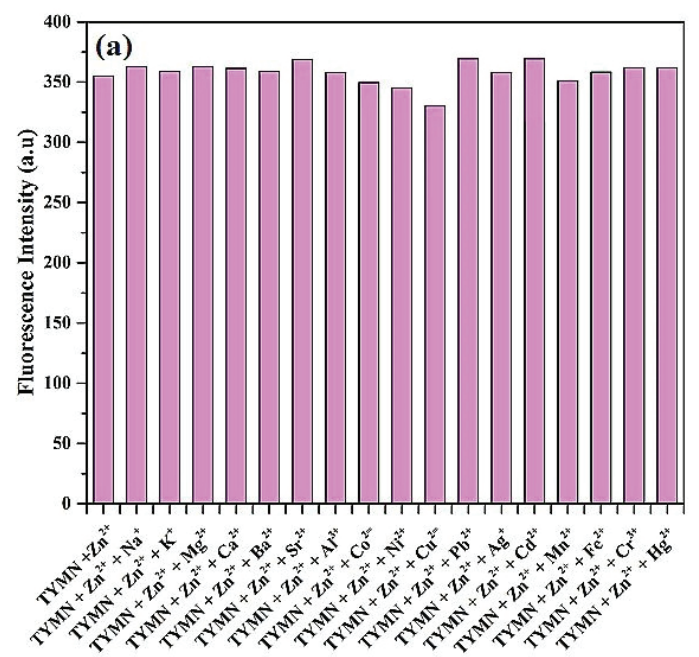

of TYMN-Zn complex were investigated by titration with EDTA. To investigate whether the enhancement of fluorescence emission intensity was actually assigned to $\mathrm{Zn}^{2+}$ ion binding with TYMN instead of photoactivation of TYMN sensor, the sensor reversibility study was performed. As seen in the Figure 9a, upon addition of EDTA to the solution containing TYMN-Zn complex, the fluorescence gradually diminished and when [EDTA] is equivalent to $\left[\mathrm{Zn}^{2+}\right]$, the fluorescence emission signal was restored to lower level of TYMN at $583 \mathrm{~nm}$, indicating regeneration of free TYMN. This inspection predicts that the complexation between $\mathrm{Zn}^{2+}$ and TYMN sensor is chemically reversible. Besides, the subsequent addition of $\mathrm{Zn}^{2+}$ ions to TYMN solution enhances fluorescence emission. This reversible enhancement process could be repeated at least five times with a little loss of fluorescent intensity (Figure 9b). These results suggested that the recognition process of TYMN probe between $\mathrm{Zn}^{2+}$ and EDTA is circularity reversible.

TYMN binding mode with $\mathrm{Zn}^{2+}$ ion

\section{Sensing mechanism speculation}

As illustrated in Scheme 2, in the absence of $\mathrm{Zn}^{2+}$ ions, TYMN fluorophore undergoes intramolecular charge transfer (ICT) from the donor to the acceptor upon photo-excitation, but in the presence of $\mathrm{Zn}^{2+}$ ions, the increase in the fluorescence intensity of TYMN can be ascribed to leakage of conjugation as a result of formation of coordinate bonds between $\mathrm{O}$ atom of hydroxyl group and the azomethine nitrogen atom, resulting in restriction of photo-induced ICT mechanism. ${ }^{47,48}$ Such mechanism causing remarkable fluorescence enhancement was previously reported. ${ }^{49}$

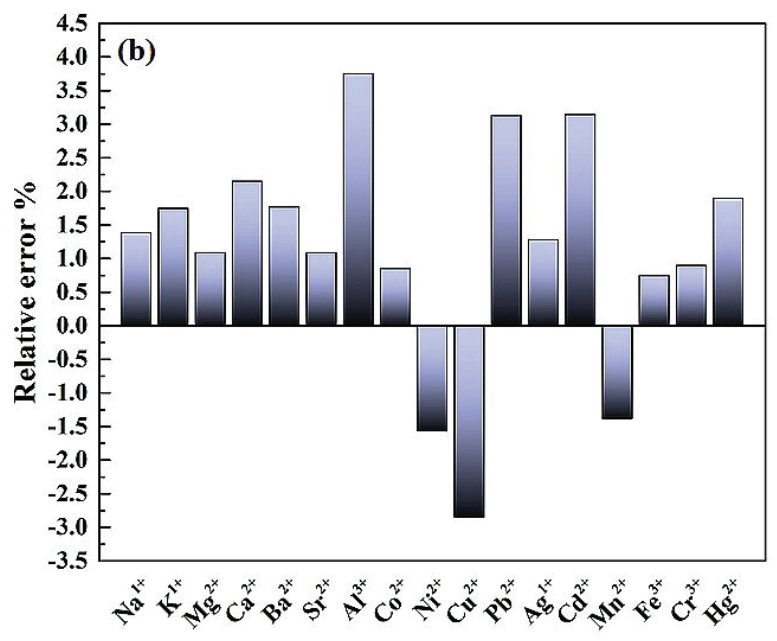

Figure 8. (a) Effects of coexisting ions $(5 \mu \mathrm{M})$ onto the fluorescence emission of TYMN-Zn ( $5 \mu \mathrm{M})$ in DMSO/ $\mathrm{H}_{2} \mathrm{O}$ at pH $7.0(\lambda \mathrm{ex}: 360 \mathrm{~nm}, \lambda \mathrm{em}: 583 \mathrm{~nm})$; (b) selectivity of TYMN probe in terms of relative error (RE). 

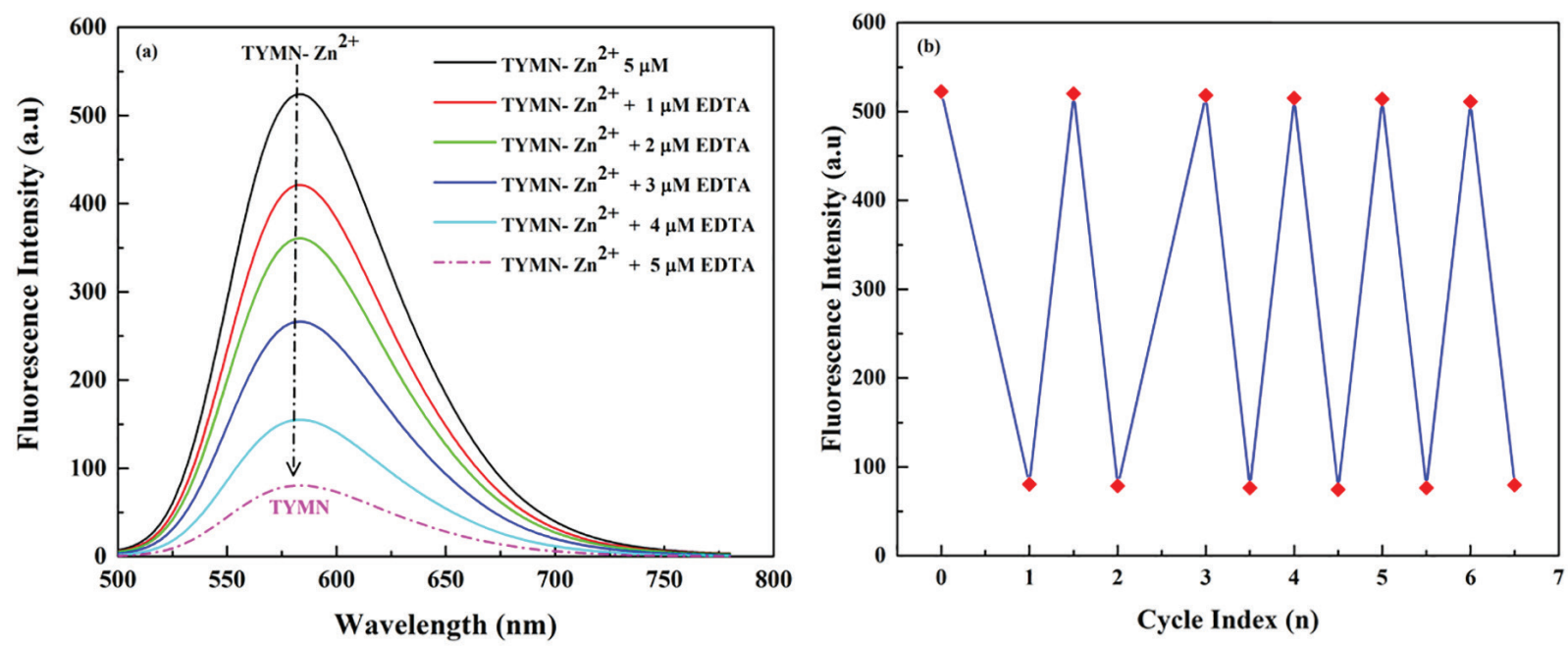

Figure 9. (a) Fluorescence spectra of TYMN-Zn $(5 \mu \mathrm{M})$ in the absence and presence of EDTA $(1-5 \mu \mathrm{M})$ in $10 \%$ (v/v) DMSO/ $\mathrm{H}_{2} \mathrm{O}$ buffered by $5 \mathrm{mM}$ HEPES at pH 7.0 at $25^{\circ} \mathrm{C}\left(\lambda_{\mathrm{ex}}=360 \mathrm{~nm}, \lambda_{\mathrm{em}}=583 \mathrm{~nm}\right)$; (b) cycle index of TYMN-Zn $(5.0 \mu \mathrm{M})$ reacting with EDTA $(5.0 \mu \mathrm{M})$.
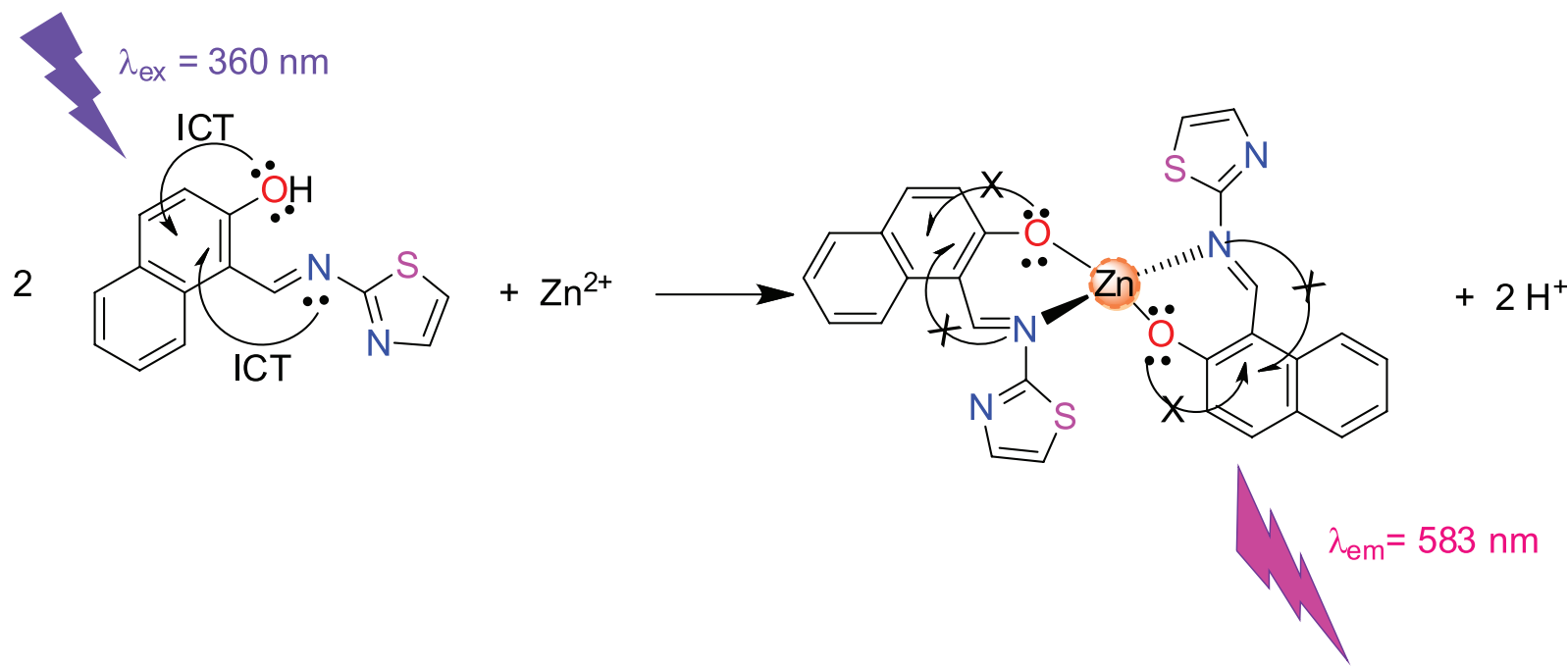

Scheme 2. The proposed binding model for the interaction between TYMN and $\mathrm{Zn}^{2+}$ ion.

Stoichiometry stability constant of the TYMN-Zn complex

Using fluorometric titration, the stoichiometry between TYMN and $\mathrm{Zn}^{2+}$ was evaluated by Job's plot. ${ }^{50}$ The total concentration of TYMN and $\mathrm{Zn}^{2+}$ was kept constant in DMSO/ $\mathrm{H}_{2} \mathrm{O}$, HEPES-buffer, pH 7.0 system, whereas mole fraction of $\mathrm{Zn}^{2+}$ ion was varied continuously. Figure 10 showed that maximum emission was achieved at $0.33 \mathrm{~mol}$ fraction of $\mathrm{Zn}^{2+}$, indicating 2:1 binding stoichiometry of the complex formed between TYMN and $\mathrm{Zn}^{2+}$ ion.

\section{Determination of binding constant}

The stoichiometry of TYMN-Zn complex was also confirmed by the Benesi-Hildebrand method. ${ }^{51}$ The binding constant of the TYMN-Zn complex formed in solution was calculated by using the standard Benesi-Hildebrand equation. ${ }^{52-54}$

$$
\frac{\mathrm{F}_{\max }-\mathrm{F}_{0}}{\mathrm{~F}-\mathrm{F}_{0}}=\frac{1}{\mathrm{~K}_{\mathrm{a}}\left[\mathrm{Zn}^{2+}\right]^{2}}
$$

where, $\mathrm{F}_{0}$ is the fluorescence intensity of free sensor TYMN; $\mathrm{F}$ is the observed fluorescence intensity at any given concentration of $\mathrm{Zn}^{2+}$ in micromolar; $\mathrm{F}_{\max }$ is the intensity at saturation point (large excess) with the $\mathrm{Zn}^{2+}$; and $\mathrm{K}_{\mathrm{a}}$ is the association constant $\left(\mathrm{M}^{-2}\right) . \mathrm{K}_{\mathrm{a}}$ was determined graphically by plotting $\left(\mathrm{F}_{\max }-\mathrm{F}_{0}\right) /\left(\mathrm{F}-\mathrm{F}_{0}\right)$ versus $1 /\left[\mathrm{Zn}^{2+}\right]^{2}$ (Figure 11). As shown in Figure 11 the data showed a good linear relationship with linear fitting with slope $=$ $\mathrm{K}_{\mathrm{a}}=6.6099 \times 10^{10}$. This value fits in the binding constants reported for $\mathrm{Zn}^{2+}$ in literature $\left(1.0-10^{12}\right) .{ }^{55}$

\section{TOF-MS-ESI+ mass}

The suggested stoichiometry of TYMN-Zn complex was corroborated with the data acquired from TOF-MS-ESI ${ }^{+}$ 


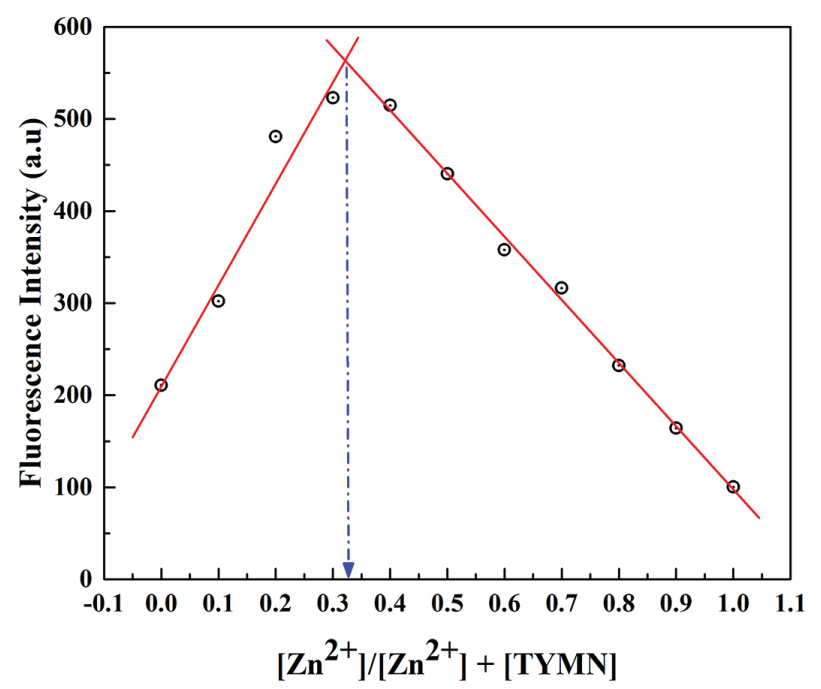

Figure 10. Job's plot for TYMN and $\mathrm{Zn}^{2+}\left([T Y M N]+\left[\mathrm{Zn}^{2+}\right]=10 \mu \mathrm{M}\right)$ in $10 \%(\mathrm{v} / \mathrm{v})$ DMSO/ $\mathrm{H}_{2} \mathrm{O}$ buffered by $5 \mathrm{mM}$ HEPES at $\mathrm{pH}$ 7.0.

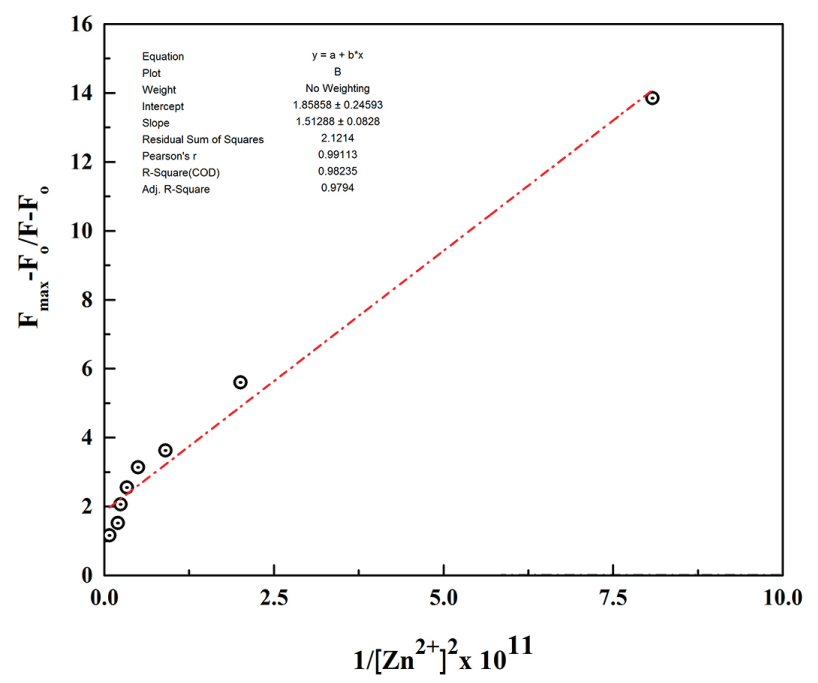

Figure 11. Benesi-Hildebrand plot for determination of TYMN-Zn association constant in DMSO/ $\mathrm{H}_{2} \mathrm{O}(1 / 9, \mathrm{v} / \mathrm{v})\left(\lambda_{\text {ex }}: 360 \mathrm{~nm}\right.$ and $\left.\lambda_{\text {ex }}: 583 \mathrm{~nm}\right)$.

electrospray ionization (ESI) mass analysis. Upon addition of $\mathrm{Zn}^{2+}$ ( 2 equiv.) to TYMN, the positive-ion mass spectrum of TYMN exhibited an intense prominent peak at $m / z 572.04$, equivalent to the ion $\left[\mathrm{Zn}(\mathrm{L})_{2}\right]$ (Figure 12) and reflecting the 1:2 binding stoichiometry of TYMN with $\mathrm{Zn}^{2+}$.

\section{${ }^{1} \mathrm{H}$ NMR titration}

Additionally, to better elucidate the complexation behavior of TYMN towards $\mathrm{Zn}^{2+}$ ions, ${ }^{1} \mathrm{H}$ NMR titration experiments were performed in DMSO- $d_{6}$. The spectral differences for free TYMN and in presence of $\mathrm{Zn}^{2+}$ are depicted in Figure 13. The ${ }^{1} \mathrm{H}$ NMR spectra showed fading of $\mathrm{OH}$ signal in free probe $(\delta 13.67 \mathrm{ppm})$ upon addition of $\mathrm{Zn}^{2+}$ ions. This signal completely disappeared upon addition of 2.0 equiv. of $\mathrm{Zn}^{2+}$ ions, confirming the induced deprotonation where the coordination of $\mathrm{Zn}^{2+}$ ion to TYMN via the oxygen of the hydroxyl group. Additionally, the coordination of azomethine nitrogen to the $\mathrm{Zn}^{2+}$ was indorsed by up-field shift the azomethine proton signal from $\delta 8.74$ to $8.36 \mathrm{ppm} .{ }^{56}$ Meanwhile, the aromatic protons multiplet displayed down field shift in the range $\delta 7.80-8.15 \mathrm{ppm}$ compared to $\delta 7.21-7.61 \mathrm{ppm}$ from those of free TYMN.

\section{Theoretical studies}

Density functional theory (DFT) calculations were performed for TYMN and TYMN- $\mathrm{Zn}^{2+}$ using DFT/B3LYP-6-31G basis set model, ${ }^{57}$ to gain insight into the fluorescence enhancement of TYMN after $\mathrm{Zn}^{2+}$ binding.

The calculations have shown that, the most stable model (energy $=13.97 \mathrm{kcal} \mathrm{mol}^{-1}$ ) displayed explicit features, with planar conformation and absence of intramolecular hydrogen bonding to any of the nitrogen and sulfur atoms, consistent with the crystal structural analysis.

Furthermore, coordination of $\mathrm{Zn}^{2+}$ ion through the nitrogen of the azomethine and the hydroxyl group was supported based on the orientation of the functional groups of TYMN. Additionally, both the X-ray ${ }^{39}$ and the theoretical analyses of the TYMN probe supported that TYMN could coordinate to metal as bidentate ligand. Finally, for TYMN-Zn complex, theoretical analysis suggested a minimum tetrahedral geometry with an energy of $265.70 \mathrm{kcal} \mathrm{mol}^{-1}, 1.92$ and $1.88 \AA$ for $\mathrm{Zn}-\mathrm{N}$ and $\mathrm{Zn}-\mathrm{O}$ bond distances, respectively. ${ }^{39}$

\section{Comparison of TYMN with recently reported probes}

The sensing ability of the developed TYMN probe for $\mathrm{Zn}^{2+}$ ion was compared to the various reported methods (Table 1). Comparing with LOD of other probes, it is clearly delineated the proposed probe shows better sensitivity for identification of $\mathrm{Zn}^{2+}$ trace amounts in real samples and best selectivity for $\mathrm{Zn}^{2+}$ quantification even in presence of $\mathrm{Cd}^{2+}$ ions.

\section{Applicability of the sensor in real samples}

To investigate the practical use of TYMN sensor in complex matrices, attempts were made to determine $\mathrm{Zn}^{2+}$ ions in some real samples including fruits, vegetables and pharmaceuticals samples. A comparison between results obtained by proposed method and FAAS was performed, for evaluating the accuracy of the proposed procedure. As can be seen in Table 2, a good agreement between the results for both methods was obtained. 
K. 79 140721145760世43 RT:50 AV: 1 NL: $4.61 \mathrm{E} 4$

T:ITMS + cESI Full ms $\mid 150-650]$
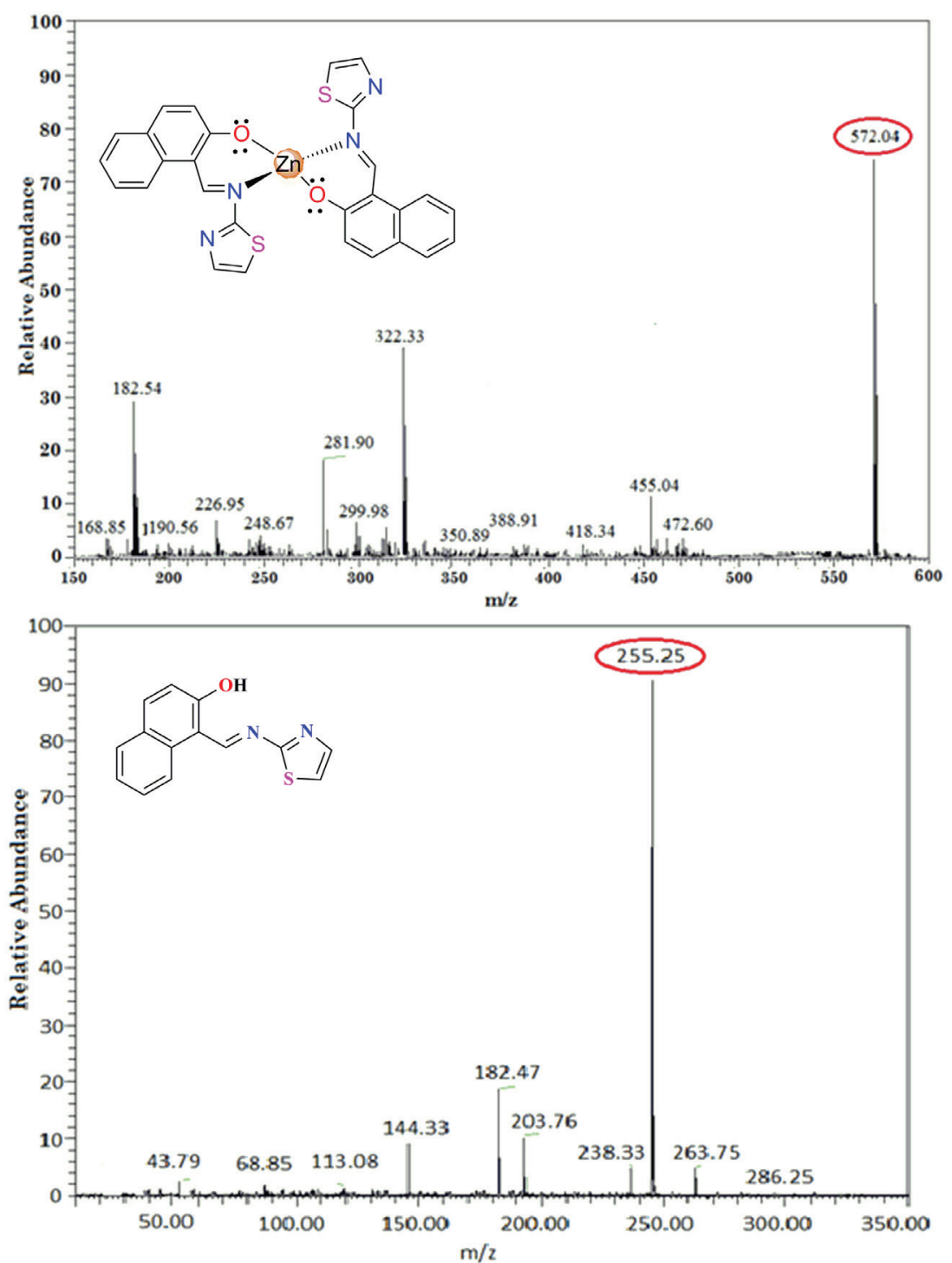

Figure 12. TOF-MS spectra of TYMN probe upon addition of $\mathrm{Zn}^{2+}$ ion (2 equiv.) in DMSO.

\section{Application in living cells}

\section{Cytotoxicity of TYMN probe}

The MTT assay was used to study the cytotoxicity of TYMN probe to HeLa cells during the staining process (Figure 14). As shown in Figure 14a, the dose dependent assay carried out for $1 \mathrm{~h}$ of incubation period, $10 \mu \mathrm{M}$ TYMN, did not show significant cytotoxic effects on HeLa cells, which suggests that TYMN can be readily used for cellular application at the indicated dose. Additionally, the cell viability assay at various time intervals of HeLa cell lines incubated with TYMN $(10 \mu \mathrm{M})$ (Figure 14b) demonstrates that to a time course of $24 \mathrm{~h}$ the cell viability rate is quite stable and only a small percentage loss of cell lines was noted. Thus, an optimal concentration of $10 \mu \mathrm{M}$ of
TYMN with an incubation period below $1 \mathrm{~h}$ was followed in all the confocal imaging studies.

\section{Bioimaging of $\mathrm{Zn}^{2+}$ in HeLa cells}

The high sensitivity, excellent selectivity, and low cell cytotoxicity of TYMN probe, open the door for potential biological application of TYMN for fluorescence imaging to detect $\mathrm{Zn}^{2+}$ in HeLa cells. As shown in Figures 15a-15c, in Dulbecco's modified Eagle's medium supplemented with $10 \%$ fetal bovine serum, HeLa cells incubated with TYMN probe solution $(10 \mu \mathrm{M})$ in $30 \mathrm{~min}$ at $37^{\circ} \mathrm{C}$ showed a weak fluorescence. On the other hand, treating TYMN-loaded cells with $\mathrm{Zn}^{2+}(20 \mu \mathrm{M})$ drastically enhance fluorescence (Figures 15d-15f) and induces strong fluorescence in the green channel. These observations indicate that TYMN 


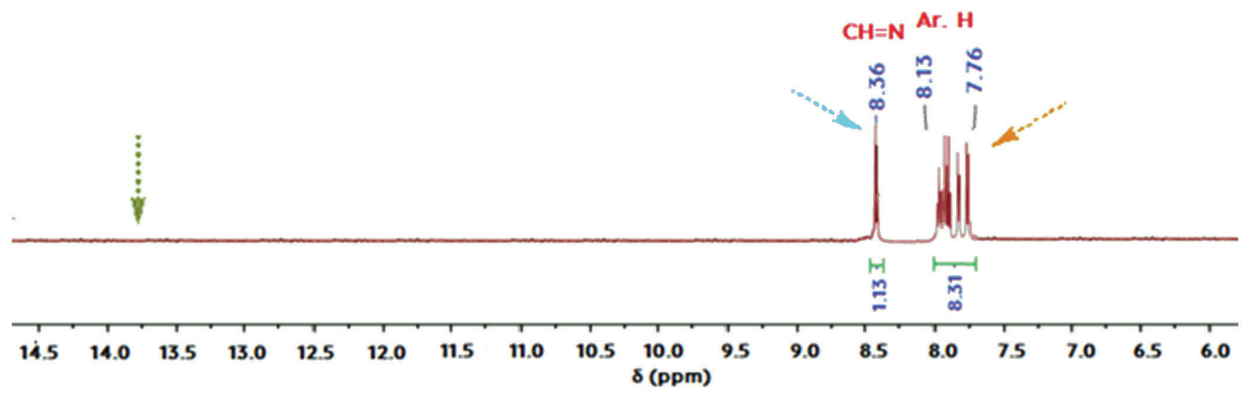

\section{0 equivalent $\mathrm{Zn}^{2+}$}

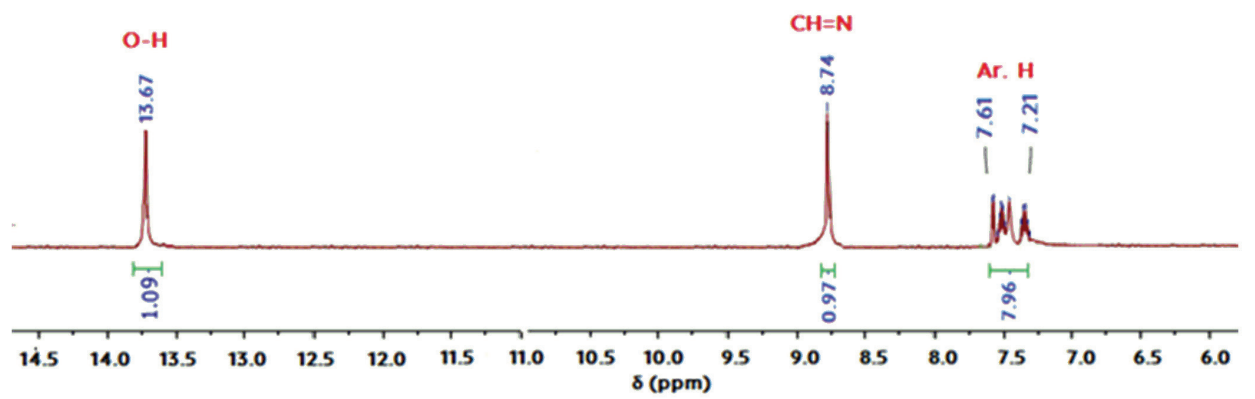

Figure 13. Partial ${ }^{1} \mathrm{H}$ NMR ( $300 \mathrm{MHz}$, DMSO- $d_{6}$ ) spectra of TYMN probe in absence (bottom) and in presence (top) of different $\mathrm{Zn}^{2+}$ equivalents.

Table 1. Comparison between the proposed probe and some recently reported simple probes for $\mathrm{Zn}^{2+}$ detection

\begin{tabular}{lccc}
\hline No. & Probe & LOD / $\mu \mathrm{M}$ & Reference \\
\hline 1 & 1-hydroxy-2-naphthaldehyde-2-pyridinehydrazone derivatives & 0.17 & 27 \\
2 & $(E)$ - $N^{\prime}$-(5-allyl-2-hydroxy-3-methoxybenzylidene)nicotinohydrazide & $4.35 \times 10^{-3}$ & 28 \\
3 & $(E)-N^{\prime}$-(2-hydroxybenzylidene)-3,5-di-tert-butyl-2-hydroxybenzo hydrazide & 2.83 & 29 \\
4 & 3 -(benzo[ $d$ ]thiazol-2-yl)-4-hydroxy-2H-chromen-2-one & 0.358 & 30 \\
5 & furan-2-carbohydrazide-5-(2-thienyl)-salicylaldehyde & 0.77 & 31 \\
6 & $N, N^{\prime}$-phenylenebis(salicylideaminato) & 0.15 & 32 \\
7 & pyridoxal-2-hydrazinopyridine Schiff-base & 0.07 & 33 \\
8 & $(E)-3-(($ thiazol-2-ylimino)methyl)naphthalen-2-ol & 0.0311 & current method \\
\hline
\end{tabular}

LOD: limit of detection.

Table 2. Determination of zinc in real samples $(n=6)$

\begin{tabular}{lccc}
\hline \multirow{2}{*}{ Sample } & \multicolumn{2}{c}{ Amount of zinc (mean \pm SD) } & Relative error / \% \\
\cline { 2 - 3 } & FAAS & Present method & -1.63 \\
Apple / $\left(\mathrm{mg} \mathrm{kg}^{-1}\right)$ & $6.1 \pm 0.19$ & $6.2 \pm 0.8$ & 1.75 \\
Grape / $\left(\mathrm{mg} \mathrm{kg}^{-1}\right)$ & $5.7 \pm 0.13$ & $5.6 \pm 0.72$ & -3.70 \\
Tomato / $\left(\mathrm{mg} \mathrm{kg}^{-1}\right)$ & $2.7 \pm 0.06$ & $2.8 \pm 0.03$ & -1.23 \\
Potato / (mg kg & $4.11 \pm 0.22$ & $24.97 \pm 0.77$ & 0.319 \\
Vitazinc capsules / (mg per capsule) & $4.06 \pm 0.37$ & $8.00 \pm 0.16$ & 0.744 \\
Calamine lotion / (mg mL & $25.05 \pm 0.98$ & $8.06 \pm 0.13$ &
\end{tabular}

SD: standard deviation; FAAS: flame atomic absorption spectrometry. 
(a)

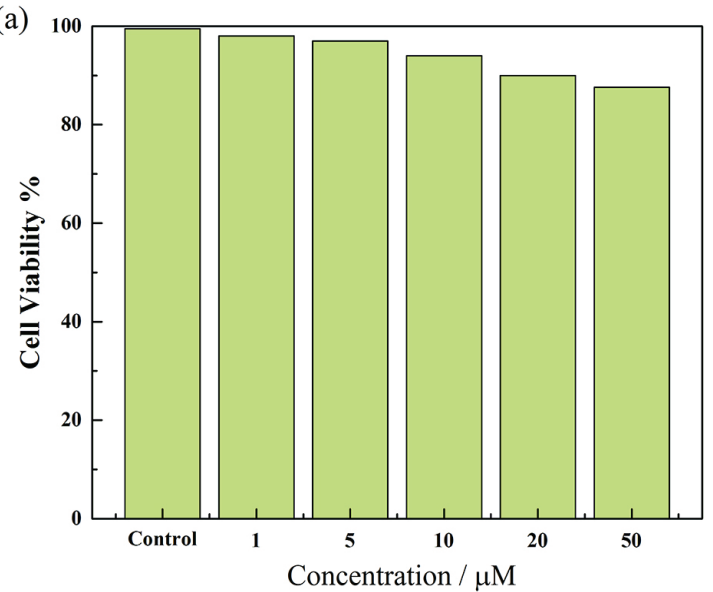

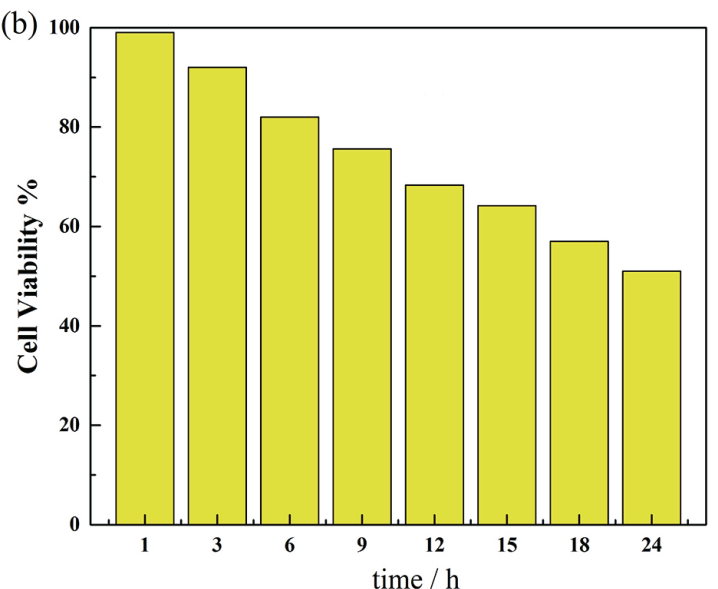

Figure 14. (a) Cytotoxicity of TYMN probe at varying concentration dependent assay; (b) cytotoxicity of TYMN probe at varying time dependent assay.
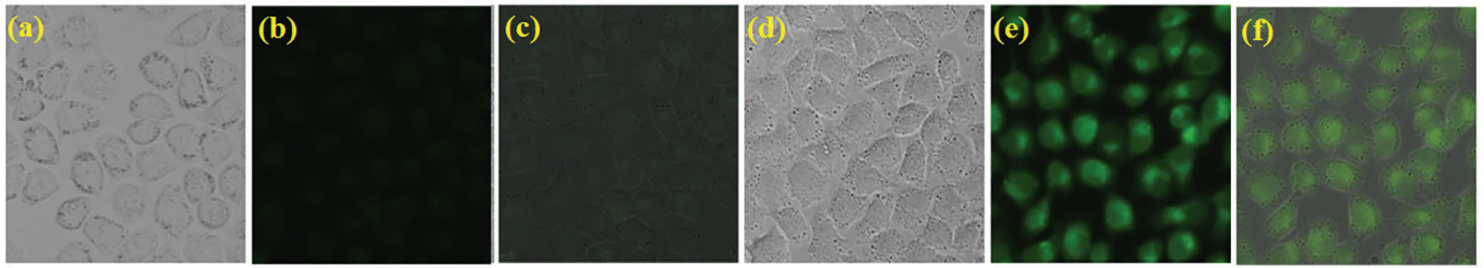

Figure 15. (a) Bright field, (b) fluorescence and (c) overlay images of HeLa cells stained with $10 \mu \mathrm{M}$ of TYMN; (d) bright field, (e) fluorescence and (f) overlay images of HeLa cells stained with $10 \mu \mathrm{M}$ of TYMN then with $20 \mu \mathrm{M} \mathrm{Zn}{ }^{2+}$.

probe had good cell-membrane permeability, which could be used for detecting $\mathrm{Zn}^{2+}$ in vivo.

\section{Conclusions}

A new Schiff base fluorophore (TYMN) for detection of zinc ions was designed, synthesized and characterized. A 1:2 stoichiometry between TYMN and $\mathrm{Zn}^{2+}$ was demonstrated by Job's plot. The probe could rapidly respond to $\mathrm{Zn}^{2+}$ with a high selectivity $(\mathrm{LOD}=0.0311 \mu \mathrm{M})$, which allows detection of zinc ions in biological and environmental samples. All biologically relevant metal ions and toxic heavy metals did not interfere with the $\mathrm{Zn}^{2+}$ ion detection with this sensor. Most significantly, fluorescence cell imaging experiments revealed that TYMN sensor has good cell-membrane permeability and can be used as a marker for sensing $\mathrm{Zn}^{2+}$ in living cells.

\section{Supplementary Information}

Supplementary data (FTIR, ${ }^{13} \mathrm{C}$ NMR spectra) are available free of charge at http://jbcs.sbq.org.br as PDF file.

\section{Acknowledgments}

The authors gratefully acknowledge Professor
Ramadan M. Ramadan, Professor of Inorganic Chemistry, Chemistry Department, Faculty of Science, Ain Shams University, Egypt for his support in theoretical calculation in this work.

\section{References}

1. Carter, K. P.; Young, A. M.; Palmer, A. E.; Chem. Rev. 2014, 114, 4564; Zhu, H.; Fan, J.; Wang, B.; Peng, X.; Chem. Soc. Rev. 2015, 44, 4337.

2. Patil, A.; Gawali, S. S.; Inorg. Chim. Acta 2018, 482, 99.

3. Şenkuytu, E.; Eçik, E. T.; Çoşut, B.; J. Lumin. 2018, 203, 639.

4. Anand, T.; Kumar, A.; Suban, S. K.; Sahoo, K.; Spectrochim. Acta, Part A 2018, 204, 105.

5. Gao, M.; Tang, B. Z.; ACS Sens. 2018, 3, 920.

6. Wang, J.; Li, Y.; Li, K.; Meng, X.; Hou, H.; Chem. - Eur. J. 2017, 23, 5081.

7. Wang, P.; Wu, X.; Wu, J.; Liao, Y.; J. Photochem. Photobiol., A 2019, 382, 111929.

8. Hambidge, K. M.; Casey, C. E.; Krebs, N. F. In Trace Elements in Human and Animal Nutrition, $5^{\text {th }}$ ed.; Mertz, W., ed.; Academic Press: San Diego, 1986, p. 1-137.

9. Wastney, M. E.; Aamodt, R. L.; Rumble, W. F.; Henkin, R. I.; Am. J. Physiol. 1986, 251, 398.

10. Kay, R. G.; Tasman-Jones, C.; Aust. N. Z. J. Surg. 1975, 45, 325. 
11. Machado, I.; Bergmann, G.; Pistón, M.; Food Chem. 2016, 194 , 373.

12. Iesari, F.; Trapananti, A.; Minicucci, M.; Filipponi, A.; Di Cicco, A.; Nucl. Instrum. Methods Phys. Res., Sect. B 2017, 411, 68.

13. Santos, A. B.; Kohlmeier, K. A.; Rocha, M. E.; Barreto, G. E.; Barreto, J. A.; de Souza, A. C. A.; Bezerra, M. A.; J. Trace Elem. Med. Biol. 2018, 47, 134.

14. Fréchette-Viens, L.; Hadioui, M.; Wilkinson, K. J.; Talanta 2019, 200, 156.

15. Petrović, S.; Guzsvány, V.; Ranković, N.; Beljin, J.; Rončević, S.; Dalmacija, B.; Ashrafi, A. M.; Kónya, Z.; Švancara, I.; Vytřas, K.; Microchem. J. 2019, 146, 178.

16. Li, K.; Wang, J.; Li, Y.; Si, Y.; Tang, B. Z.; Sens. Actuators, B 2018, 274, 654.

17. Czarnik, A. W.; Fluorescent Chemosensors for Ion and Molecule Recognition, $1^{\text {st }}$ ed.; American Chemical Society: Washington, 1992.

18. Xu, Z.; Yoon, J.; Spring, D. R.; Chem. Soc. Rev. 2010, 39, 1996.

19. Liu, Y.; Li, Y.; Feng, Q.; Li, N.; Li, K.; Hou, H.; Zhang, B.; Luminescence 2018, 33, 29.

20. Wang, P.; Zhou, D.; Chen, B.; Spectrochim. Acta, Part A 2018, 204,735 .

21. Li, W.; Liu, Z.; Fang, B.; Jin, M.; Tian, Y.; Biosens. Bioelectron. 2020, 148, 111666.

22. Shirbhate, M. E.; Jeong, Y.; Ko, G.; Baek, G.; Kim, G.; Kwon, Y.-U.; Kim, M. K.; Yoon, J.; Dyes Pigm. 2019, 167, 29.

23. Hu, Z.; Yang, G.; Hu, J.; Wang, H.; Eriksson, P.; Zhang, R.; Zhang, Z.; Uvdal, K.; Sens. Actuators, B 2018, 264, 419.

24. Wang, P.; Wu, J.; An, Y.; Liao, Y.; Spectrochim. Acta, Part A 2019, 220, 117140.

25. Zhang, Y.-P.; Xue, Q.-H.; Yang, Y.-S.; Liu, X.-Y.; Ma, C.-M.; Ru, J.-X.; Guo, H.-C.; Inorg. Chim. Acta 2018, 479, 128.

26. Kumar, S. S.; Kumar, R. S.; Ashok, S. K.; Inorg. Chim. Acta 2020, 502, 119348.

27. Lin, H. Y.; Chen, T. Y.; Liu, C. K.; Wu, A. T.; Luminescence 2016, 31, 236.

28. Patil, M.; Bothra, S.; Sahoo, S. K.; Rather, H. A.; Vasita, R.; Bendre, R.; Kuwar, A.; Sens. Actuators, B 2018, 270, 200.

29. Naik, K.; Revankar, V.; J. Fluoresc. 2018, 28, 1105.

30. Jonaghani, Z. M.; Zali-Boeini, J. H.; Moradi, H.; Spectrochim. Acta, Part A 2019, 207, 16.

31. Feng, Q.; Li, Y.; Li, K.; Lu, J.; Wang, J.; Fan, P.; Li, D.; Wu, D.; Hou, H.; ChemistrySelect 2017, 2, 3158.

32. Hosseini, M.; Vaezi, Z.; Ganjali, M. R.; Faridbod, F.; Abkenar, S. D.; Alizadeh, K.; Salavati-Niasari, M.; Spectrochim. Acta, Part A 2010, 75, 978.

33. Li, Y.; Li, K.; He, J.; Talanta 2016, 153, 381.

34. Aziz, A. A. A.; Seda, S. H.; Sens. Actuators, B 2014, 197, 155.

35. Aziz, A. A. A.; Seda, S. H.; J. Fluoresc. 2015, 25, 1711.
36. Aziz, A. A. A.; Mohamed, R. G.; Elantabli, F. M.; El-Medani, S. M.; J. Fluoresc. 2016, 26, 1927.

37. Aziz, A. A. A.; Seda, S. H.; Mohammed, S. F.; Sens. Actuators, B 2016, 223, 566.

38. Schwarzenbach, G.; Flaschka, H.; Complexometric Titrations, $2^{\text {nd }}$ ed.; Methuen: London, 1969, p. 260.

39. Mohamed, R. G.; Makhlouf, A. A.; Mosad, S. A.; Aziz, A. A. A.; El-Medani, S. M.; Ramadan, R. M.; J. Coord. Chem. 2018, 71,3665 .

40. Williams, A. T. R.; Winfield, S. A.; Miller, J. N.; Analyst 1983, 108, 1067.

41. Parker, C. A.; Rees, W. T.; Analyst 1960, 85, 587.

42. Crosby, G. A.; Demas, J. N.; J. Phys. Chem. 1971, 75, 991.

43. Zhou, X.; Yu, B.; Guo, Y.; Tang, X.; Zhang, H.; Liu, W.; Inorg. Chem. 2010, 49, 4002.

44. Aziz, A. A. A.; J. Lumin. 2013, 143, 663.

45. Wen, J.; Geng, Z.; Yin, Y.; Zhang, Z.; Wang, Z.; Dalton Trans. 2011, 40, 1984.

46. Long, G. L.; Winefordner, J. D.; Anal. Chem. 1983, 55, 712A.

47. Jiao, Y.; Zhu, B.; Chen, J.; Duan, X.; Theranostics 2015, 5, 173.

48. Sadia, M.; Naz, R.; Khan, J.; Khan, R.; J. Fluoresc. 2018, 28, 1281.

49. Wang, J.; Qian, X.; Cui, J.; J. Org. Chem. 2006, 71, 4308.

50. Vosburgh, W. C.; Copper, G. R.; J. Am. Chem. Soc. 1941, 63, 437.

51. Benesi, H. A.; Hildebrand, J. H.; J. Am. Chem. Soc. 1949, 71, 2703.

52. Ahumada, M.; Lissi, E.; Montagut, A. M.; ValenzuelaHenríquez, F.; Pacioni, N. L.; Alarcon, E. I.; Analyst 2017, 142, 2067.

53. Conners, K. A.; Binding Constants - The Measurement of Molecular Complex Stability; John Wiley \& Sons: New York, 1987.

54. Li, Y.; Wu, J.; Jin, X.; Wang, J.; Han, S.; Wu, W.; Xu, J.; Liu, W.; Yao, X.; Tang, Y.; Dalton Trans. 2014, 43, 1881.

55. Budri, M.; Chimmalagi, G.; Naik, G.; Patil, S.; Gudasi, K.; Inamdar, S.; J. Fluoresc. 2019, 29, 1065.

56. Aziz, A. A. A.; Seda, S. H.; J. Fluoresc. 2017, 27, 1051.

57. Frisch, M. J.; Trucks, G. W.; Schlegel, H. B.; Scuseria, G. E.; Robb, M. A.; Cheeseman, J. R.; Montgomery Jr., J. A.; Vreven, T.; Kudin, K. N.; Burant, J. C.; Millam, J. M.; Iyengar, S. S.; Tomasi, J.; Barone, V.; Mennucci, B.; Cossi, M.; Scalmani, G.; Rega, N.; Petersson, G. A.; Nakatsuji, H.; Hada, M.; Ehara, M.; Toyota, K.; Fukuda, R.; Hasegawa, J.; Ishida, M.; Nakajima, T.; Honda, Y.; Kitao, O.; Nakai, H.; Klene, M.; Li, X.; Knox, J. E.; Hratchian, H. P.; Cross, J. B.; Bakken, V.; Adamo, C.; Jaramillo, J.; Gomperts, R.; Stratmann, R. E.; Yazyev, O.; Austin, A. J.; Cammi, R.; Pomelli, C.; Ochterski, J. W.; Ayala, P. Y.; Morokuma, K.; Voth, G. A.; Salvador, P.; Dannenberg, J. J.; Zakrzewski, V. G.; Dapprich, S.; Daniels, A. D.; Strain, M. C.; Farkas, O.; Malick, D. K.; Rabuck, A. D.; Raghavachari, K.; 
Foresman, J. B.; Ortiz, J. V.; Cui, Q.; Baboul, A. G.; Clifford, S.; Cioslowski, J.; Stefanov, B. B.; Liu, G.; Liashenko, A.; Piskorz, P.; Komaromi, I.; Martin, R. L.; Fox, D. J.; Keith, T.; Al-Laham, M. A.; Peng, C. Y.; Nanayakkara, A.; Challacombe, M.; Gill, P. M. W.; Johnson, B.; Chen, W.; Wong, M. W.; Gonzalez,
C.; Pople, J. A.; Gaussian 03, Revision C.02; Gaussian, Inc., Wallingford, CT, 2004.

Submitted: November 11, 2019 Published online: March 18, 2020 